\title{
Allergic bronchopulmonary aspergillosis among patients with bronchial asthma
}

\author{
Al-Najada M, Al-Nadi K, Sharara AM \\ Department of chest disease, King Hussein Medical Centre, amman -jordan
}

\begin{abstract}
Objective

To determine the different presentations encountered upon diagnosis of ABPA among patients with bronchial asthma and the two-year-follow-up results.
\end{abstract}

\section{Patients and method}

All patients with bronchial asthma and ABPA were included in the study .Specially formulated sheet was done include age, gender, duration of bronchial asthma ,new clinical,radiological,and laboratory findings suggestive of ABPA and two year follow up of them. Diagnosis of ABPA was based on Rosenberg-Patterson criteria.

\section{Result}

Fifteen patients with ABPA 3.9\% out of 385 patients with bronchial asthma were included in our study, (5males)and (10 females) there mean age was 28.8 years, and mean duration of asthma was 8.9 years, and they represent all stages of asthma severity. Fleeting shadows mainly in the upper lobes were the most common radiological findings observed in nine patients (60\%), five patients $(33.3 \%)$ had proximal bronchiectasis detected by high resolution chest ct-scan, one of our patients had collapsed consolidation. All patients had moderate to severe eosinophilia and positive immediate skin test for aspergillus.

\section{Conclusion}

As the prevalence of ABPA is not uncommon among patients with bronchial asthma regardless the severity and the level control of asthma, high index of suspicious for ABPA should be maintained when followed up any patient with bronchial asthma.

\section{Introduction}

Allergic bronchopulmonary aspergillosis (ABPA) is an immunologically mediated lung disease characterized by a complex hypersensisitivity reaction in patients with asthma which occurs when bronchi become colonized by Aspergillus.Repeated episodes of bronchial obstruction inflammation and mucoid impaction can lead to bronchiectasis, fibrosis, and chronic lung disease.

The clinical manifestation of pulmonary aspergillosis is variable and range from saprophytic aspergillosis in the form of aspergilloma to chronic necrotizing pulmonary aspergillosis, and invasive aspergillosis( Soubani AO, Chandrasekar PII ,2000).
The prevalence of ABPA in patients with bronchial asthma ranged from 3.7 to $11 \%$ in western countries (Henderson AII et al,1968;Agbayani BF et al,1967).And in India the prevalence reached 16\% (Kumar and Gaur 2000).

\section{Material and Methods:}

Specially formulated data sheet was done to all patients with ABPA and bronchial asthma, who are on regular follow up in the chest department at King Hussein Medical Centre (KHMC).

The sheet included age ,gender, duration of bronchial asthma, clinical presentation, radiological and laboratory findings and skin testing .The diagnosis of ABPA was made using Rosenberg-Patterson 
criteria(Rosenberg M et al ,1977; Patterson $\mathrm{R}$ et al ,1986) which include major and minor criteria.

major criteria include (1)history of bronchial asthma,(2)fleeting or fixed pulmonary shadows,(3)positive immediate skin test for aspergillus,(4)serum IgE level $>1000 \mathrm{IU} / \mathrm{ml},(5)$ eosinophilia,(6)proximal bonchiectasis,(7)raised specific serum IgE and $\operatorname{IgG}$ against aspergillus fumigates,(8)precipitating antibody against aspergillus fumigatus ,and minor criteria include (1) sputum culture positive for aspergillus fumigates,(2)type III cutaneous reactivity to aspergillus fumigates,(3)expectoration of mucus plugs. In our study at least six criteria had to be present for diagnosis of allergic bronchopulmonary aspergillosis.

\section{Results}

Fifteen patients with ABPA (3.9\%) were found out of 384 patients with bronchial asthma included in our study (table 1), (5males)and (10 females) there mean age was 28.8 years and mean duration of asthma was 8.9 years, and they represent all stages of asthma, three of them(20\%) were smoker.

Eight patients (53\%) described other allergic disorders like allergic rhinitis and eczema, and eight patients (53\%) gave a history of family atopy.All patients presented with exacerbation of cough, dyspnoea and wheezes, five patients $(33.3 \%)$ described expectoration of mucus plugs, and two patients (13.3\%) had haemoptysis.

Fleeting shadows mainly in the upper lobes were the most common radiological findings observed in nine patients $(60 \%)$, five patients $(33.3 \%)$ had proximal bronchiectasis detected by high resolution chest ct-scan, one of our patients had collapsed consolidation.

Nine patients $(60 \%)$ had absolute eosinophils counts above 1000 cells $/ \mu \mathrm{L}$, and sex patients (40\%) had eosinophils counts between $500-1000$ cells/ $\mu \mathrm{L}$.

Immediate skin test showed typeI reactivity in all patients, and serum precipitins (IgG) against aspergillus fumigate was positive in all patients.

Serum total IgE concentration was greater than $1000 \mathrm{IU} / \mathrm{mL}$ in all patients.

All patients were followed up for two years, those with fleeting shadows had smooth coarse without any new radiological findings, and those with bronchiectasis had frequent exacerbations ,but none of them developed any new radiological finding.

Table 1

\begin{tabular}{|l|l|l|}
\hline Clinical profile & Number(absolute) & percentage \\
\hline Male & $5 / 15$ & 33.3 \\
\hline Female & $10 / 15$ & 66.6 \\
\hline Mean age & 28.8 & \\
\hline Smoking history & $3 / 15$ & 20 \\
\hline $\begin{array}{l}\text { History of Bronchial } \\
\text { asthma }\end{array}$ & $15 / 15$ & 100 \\
\hline Mean duration of asthma & 8.9 & \\
\hline Other allergic disorders & $8 / 15$ & 53.3 \\
\hline
\end{tabular}




\begin{tabular}{|c|c|c|}
\hline Family history of atopy & $8 / 15$ & 53.3 \\
\hline $\begin{array}{l}\text { Symptoms } \\
\text { Cough } \\
\text { Mucus plug } \\
\text { Dyspnea } \\
\text { Wheezes } \\
\text { haemoptysis }\end{array}$ & $\begin{array}{l}15 / 15 \\
5 / 15 \\
15 / 15 \\
15 / 15 \\
2 / 15\end{array}$ & $\begin{array}{l}100 \\
33.3 \\
100 \\
100 \\
13.3\end{array}$ \\
\hline $\begin{array}{l}\text { Radiological findings } \\
\text { Normal } \\
\text { Fleeting shadows } \\
\text { Proximal } \\
\text { bronchectasis } \\
\text { Collapse } \\
\text { consolidation } \\
\end{array}$ & $\begin{array}{l}\text { None } \\
9 / 15 \\
5 / 15 \\
1 / 15\end{array}$ & $\begin{array}{l}60 \\
33.3 \\
6\end{array}$ \\
\hline $\begin{array}{l}\text { Absolute eosinophils count } \\
500 \\
500-1000 \\
1000\end{array}$ & $\begin{array}{l}\text { None } \\
6 / 15 \\
9 / 15\end{array}$ & $\begin{array}{l}40 \\
60\end{array}$ \\
\hline $\begin{array}{l}\text { Immediate skin test } \\
\text { reactivity to aspergillus } \\
\text { antigen }\end{array}$ & $15 / 15$ & 100 \\
\hline $\begin{array}{l}\text { Serum total } \mathrm{IgE} \\
\text { concentration greater than } \\
1000 \mathrm{IU} / \mathrm{mL}\end{array}$ & $15 / 15$ & 100 \\
\hline $\begin{array}{l}\text { Serum precipitin against } \\
\text { aspergillus }\end{array}$ & $15 / 15$ & 100 \\
\hline $\begin{array}{l}\text { Aspergillus specific } \\
\text { IgE/IgG }\end{array}$ & Not done & \\
\hline
\end{tabular}

\section{Discussion:}

The pathogenesis of ABPA is still not fully understood. Repeated inhalation of aspergillus spores especially aspergillus fumigates leads to airway colonization in sputum plugs in the bronchi of asthmatic patients with little or no tissue invasion ( Raj Kumar et al, 2003).

The clinical classification of ABPA set by Patterson et al(1982) includes five stages, (see table 2); stage I (acute), stage II (remission), stageIII (exacerbation), stage IV (steroid dependent ABPA), stage V (fibrosis-end stage). The classification proposed by Kumar (2003) was based on radiological findings and includes three stages 1) ABPA-S (serological positive without bronchiectasis), 2) ABPA-CB (with central bronchiectasis), 3)ABPA-CB-ORF (with central bronchiectasis and other radiological findings).

ABPA is quite not uncommon in patients with bronchial asthma, it was found in $(3.9 \%)$ of our patients with bronchial asthma. The prevalence of ABPA range from 3.7 to $11 \%$ in western countries (Henderson AII et al,1968;Agbayani BF et $a l, 1967)$. In the study done by Kumar and Gaur (2000) from India the incidence of ABPA in asthmatics reached up to $16 \%$. The most common radiological finding of ABPA in our study was the fleeting shadows, It is found in $60 \%$ of our patients which nearly similar to that $(69 \%)$ in Kumar and Gaur study (2000). All of our 
patients had high absolute eosinophilic count a finding that should always alert the clinician to the possibility of ABPA in patient with asthma, the same findings were seen in Kumar and Gaur study (2000), and Chakrbarti et al . study (2002). During the 2 years follow up the nine patients who presented with fleeting shadows had smooth course, none of them reached stage IV (steroid dependent ABPA),but unfortunately two of them lost follow up for one year , and they return back with severe symptoms ,ended with steroid dependent ABPA without any new radiological findings. This outcome was similar to that reported in Kumar R study (2003) and Greenberger PA et al study (1993).

All patients who primarily presented with proximal bronchiectasis (ABPA-CB) had recurrent exacerbation, but none of them developed other radiological findings.

None of our patients included in the study, developed new radiological findings during the 2 year follow up, but many of them had frequent exacerbation and needed oral corticosteroid therapy.

The natural history of ABPA is poorly characterized and is difficult to predict 17,8,15 ( Wang JL et al 1979; Lee TM et al 1987; Rosenberg M et al 1978).An early diagnosis and initiation of systemic corticosteroid is essential to prevent irreversible damage ( Patterson R 1998).
The course of patients who presented primarily with (ABPA-S) looks to be less severe than those who presented with (ABPA-CB), and this also was observed in the study done on 18 patients with ABPA by Raj Kumar (2003), and in another study done by Kumar and Chopra (2002).

In a multivariate analysis of 155 patients with ABPA done by Agawal and colleagues (2007) they demonstrated that the severity of bronchiectasis and presence of hyperattenuating mucoid impaction on HRCT-predicted relapses of ABPA and the severity of bronchiectasis was an independent predictor of failure to achieve long-term remission.

\section{Conclusion}

As the prevalence of ABPA is not uncommon among patients with bronchial asthma regardless the severity and the level control of asthma, high index of suspicious for ABPA should be maintained when followed up any patient with bronchial asthma.An immediate skin test for aspergillus fumigates should be done for every patient with bronchial asthma, and if positive other immunological studies should be requested for diagnosis or exclusion of ABPA, this is because early diagnosis and treatment of ABPA will prevent irreversible damage.

Table 2

\begin{tabular}{|c|c|c|c|}
\hline stages & Clinical picture & Biology & Radiological findings \\
\hline I)Acute & $\begin{array}{l}\text { fever,coygh,haemoptysis,weig } \\
\text { ht loss, sputum }\end{array}$ & $\begin{array}{l}\text { level tol serum IgE } \\
\mp \text { blood } \\
\mp \text { blood } \\
\text { eosinophilia }\end{array}$ & $\begin{array}{l}\text { Normal or pulmonary } \\
\text { infiltrates(upper/middle } \\
\text { lobes }\end{array}$ \\
\hline II)Remission & asymptomatic & $\begin{array}{l}\text { Normal or thtotal } \\
\text { serum IgE level }\end{array}$ & $\begin{array}{l}\text { Normal or significant } \\
\text { resolution of radiological } \\
\text { infiltrates from the acute } \\
\text { stage }\end{array}$ \\
\hline III)Exacerbation & $\begin{array}{l}\text { allergic bronchopulmonary } \\
\text { aspergillosis }\end{array}$ & $\begin{array}{l}\text { Doubling of } \operatorname{IgE} \\
\text { level from the } \\
\text { baseline }\end{array}$ & $\begin{array}{l}\text { Transient or fixed } \\
\text { pulmonary infiltrates }\end{array}$ \\
\hline IV)Glucocorticoid -dependent & Sever persistent asthma & Normal or & Transient or fixed \\
\hline
\end{tabular}


Sever pulmonary dysfunction, fixed airway obstruction, type II respiratory failure, cor pulmonale

\section{Normal or elevated serum IgE level}

Extensive Bronchiectasis, pulmonary fibrosis, pulmonary hypertension

\section{References}

1 Agarwal R , Gupta D, Aggarwal AN, et al. (2007):clinical significance ofhyperattenuation mucoid impaction in allergic bronchopulmonary aspergillosis :an analysis of 155 patients.Chest;132:1183-1190

2 Agbayani BF, Normal PS, Wekenwerden $\mathrm{W}$,et al.(1967):The evidence of allergic aspergillosis in chronic asthma.J Allergy,40:319-326

3 Chakrabarti A,Senthi S , Raman DSV ,Behera D. (2002): Eight-year study of allergic bronchopulmonary aspergillosis in an Indian teaching hospitals.Mycoses, 45:295-299

4 Greenberger PA, Miller TP ,Roberts M, et al. (1993):Allergic bronchopulmonary aspergillosis in patients with and without bronchiectasis .Ann Allergy,70:333-338

5 Henderson AII,English MP,Vecht RJ. (1968 ):Pulmonary aspergillosis:a survey of its occurrence in patients with chronic lung disease and a discussion of significance of diagnostic test.thorax,25:513-553

6 Kumar R. (2003): Mild, moderate, and severe forms of allergic bronchopulmonary aspergillosis: a clinical and serologic evaluation. Chest, 124:890-892

7 Kumar R ,Gaur SN . (2000): prevalence of allergic bronchopulmonary aspergillosis in patients with bronchial asthma.Asian Pac J Allergy Immunol , 18:181-185

8 Lee TM, Greenberger PA, Patterson R, et al.( 1987):Stage V(fibrotic) allergic bronchopulmonary aspergillosis: a review or 17 cases followed from diagnosis. Arch Intern Med , 147:319-323

9 Patterson R.( 1998):Allergic bronchopulmonary aspergillosis and hypersensitivity reactions to fungi. In: Fishman AP , Elias JA, Fishman JA, et al, eds. Fishman's pulmonary diseases and disorders. New York, NY: McGraw-IIill,; 777-782

10 Patterson R, Greenberger PA, IIalwig JM, et al. (1986 ):Allergic bronchopulmonary aspergillosis: natural history and classification of early disease by serologic and roentgenographic studies. Arch Intern Med, 146:916-918

11 Patterson R, Greenberger PA, Radian RC, et al. (1982): Allergic bronchopulmonary aspergillosis: staging as an aid to management. Ann Intern Med, 96:286-291

12 Raj Kumar, Deepti Chopra.( 2002):Evaluation of allergic bronchopulmonary aspergillosis in patients with and without central bronchiectasis. Journal of asthma, 39(6) : 473477.

13 Raj Kumar, tarun chugh,S. N. Gaur . (2003): allergic bronchopulmonary aspergillosis - a review. Indian J allergy asthma immunol,17(2) :55-66

14 Rosenberg M, Patterson R, Mintzer R, et al. (1977 ): Clinical and immunologic criteria for the diagnosis of allergic bronchpulmonary aspergillosis. Ann Intern Med, 86:405-414

15 Rosenberg M, Patterson R, Roberts M, et al. (1978): The assessment of immunologic and clinical changes occurring during corticosteroid therapy for allergic bronchopulmonary aspergillosis. Am J Med, 64:599-606

16 Soubani AO, Chandrasekar PII.(2002): The clinical spectrum of pulmonary aspergillosis. Chest, 121:1988-1999

17 Wang JL, Patterson R, Roberts M, et al. (1979):The management of allergic bronchopulmonary aspergillosis. Am Rev Respir Dis, 120:87-92 


\section{داء الرئة والقصبات الفطري التحسسي بالاسبيرجلس}

د.محمد النجادا د.خالد النادى د. دبدالمنعم شرارة

قسم الامر اض الصدرية- مدينة الحسين الطبية - عمان-الاردن فيدارة

الهُف:- لتحديد الصور المختلفة التي تو اجه عند تشخيص داء الرئة والقصبات الفطري التحسي بالاسبيرجلس عند مرضى الربو القصبي خلال سنتين ومتابعة النتائج.





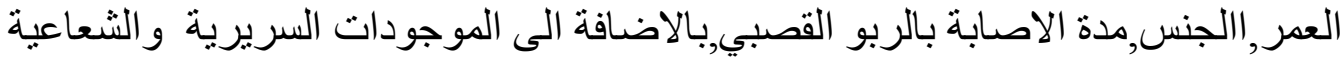
و المخبرية الجديدةالتي ترجح الاصبابة بداء الرئة و القصبات الفطري التحسسي ومتابعة هؤلاء

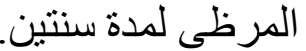
المعايير التي اعتمدت في تشخيص المرض هي معايير روزنبيرغ غاترسون.

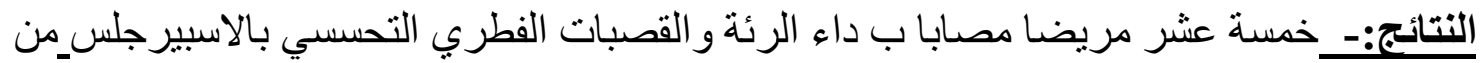

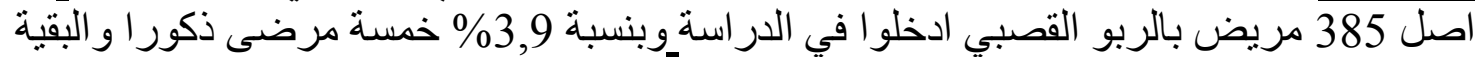

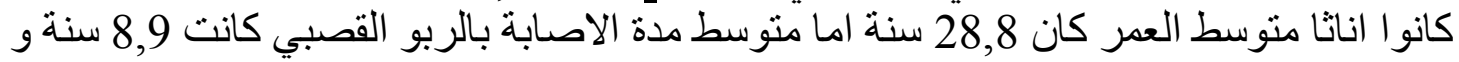

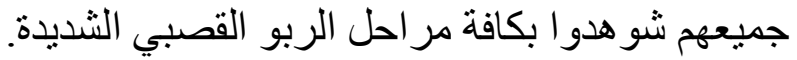

اكثر المظاهر الشعاعية شيو عا كانت الارتشاحات سريعة الزو ال في الفصوص الرئية الرئوية العلوية

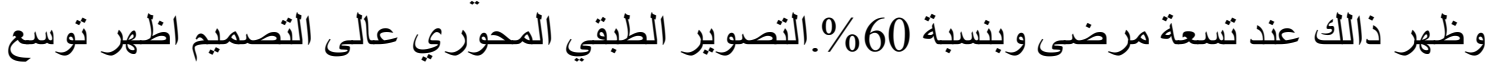
القصبات الهوائية المركزي عند خمسة مرضى وبنسبة 33,3\%. مريض و احد كان عنده كثافة



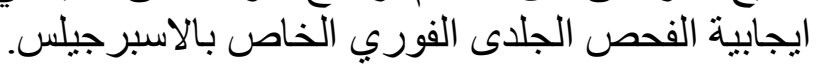

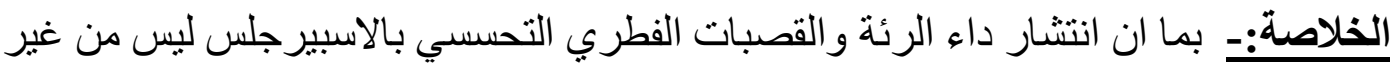

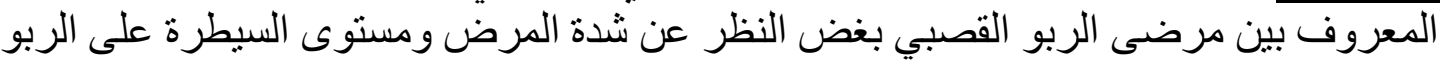
القصبي.ارتفاع مؤشر الاشتباة بالمرض يجب الرين ان يتابع عند أي مريض مصناب ب الربوض القصبي. 